\title{
PENGARUH EDUKASI TERHADAP PENGETAHUAN KEBERSIHAN TANGAN SISWA SEKOLAH DASAR KOMUNITAS ANAK ASUH RIMBANI
}

\author{
${ }^{1}$ Izza Suraya, ${ }^{1}$ Yoli Farradika, ${ }^{1}$ Rina Khairunnisa \\ ${ }^{1}$ Fakultas IImu Kesehatan, Universitas Muhammadiyah Prof. DR. HAMKA, \\ email : izza suraya@uhamka.ac.id
}

\begin{abstract}
ABSTRAK
Kebersihan tangan seringkali terabaikan oleh anak yang tinggal dalam sosial ekonomi kurang baik. Hal ini diakibatkan kuranganya pengetahuan mereka akan hal tersebut. Oleh karena itu, edukasi tentang kebersihan tangan perlu diberikan kepada anak komunitas Anak Asuh Rimbani. Untuk melihat pengaruh edukasi tersebut, maka studi ini perlu dilakukan.

Studi ini merupakan penelitian dengan desain pre-post test experimental untuk mengetahui pengetahuan anak sebelum dan sesudah dilakukan edukasi. Populasi dalam penelitian ini adalah anak kelas 2-4 sekolah dasar yang terdaftar sebagai penerima bantuan belajar di komunitas Anak Asuh Remaja Islam Baitul Mughni. Dengan teknik sampling jenuh dan peserta yang datang sebagai kriteria inklusiya, maka diperoleh 41 orang anak sebagai sampel penelitian. Untuk melihat perbedaan rata-rata pengetahuan anak sebelum dan sesusdh intervensi, dilakukan uji paired t-test.

Hasil studi menunjukkan bahwa terjadi peningkatan pengetahuan peserta dari sebelum diberikan penyuluhan dan dilakukan praktek dengan setelah diberikan penyuluhan dan dilakukan praktek, dengan nilai $p<0,001$. Rerata skor pre-test peserta adalah 2,93 (SD $=0,91)$ dan rerata skor post-test adalah $3,85(S D=1,04)$.
\end{abstract}

Kata kunci : kebersihan tangan, edukasi lagu, anak asuh

\section{PENDAHULUAN}

Berbagai macam penyakit ditularkan secara tidak langsung melalui makanan yang masuk ke dalam tubuh, diantaranya adalah diare, kolera, disentri, kecacingan, typoid, dan hepatitis. Menurut Diektorat Jendral Pengendalian Penyakit dan Penyehatan Lingkungan (P2PL) Departemen Kesehatan pada tahun 2009 sebanyak $31,8 \%$ siswa SD di Indonesia mengalami kecacingan (A.K, 2012). Sementara itu, anak SD yang meninggal karena diare mencapai angka 2,94\% (Kementerian Kesehatan, 2011). Sebagian besar anak yang tergabung dalam Anak Asuh Remaja Islam Baitul Mughni (A2R), Kuningan Timur Jakarta
Selatan, merupakan siswa SD yang rentan terhadap penyakit tersebut.

Berdasarkan kondisi sosial ekonomi, anak asuh dalam komunitas tersebut adalah anak dengan keluarga kurang mampu yang tinggal di sekitar masjid Baitul Mughni, Kuningan Timur, Jakarta Selatan. Berdasarkan hasil observasi, beberapa orang anak merupakan anak yatim atau piatu sementara yang lain memiliki orang tua dengan pekerjaan sebagai buruh lepas dengan upah tidak menentu.

Sedangkan ditinjau dari lingkungan tempat tinggal, sebagaian besar dari anak asuh Rimbani tinggal di daerah bantarab kali Kuningan. Pemukiman tempat tinggal 
mereka adalah daerah padat dan kumuh. Selain itu, masih terdapat WC umum yang terletak di luar ruma yang sangat memungkinkan mencemari saluran air ke lingkunagan rumah.

Sebagian besar anak asuh Rimbani merupakan anak siswa SD dengan latar belakang sosial ekonomi kurang baik. Selain itu, mereka mempunyai lingkungan tempat tinggal yang tidak sehat. Dengan demikian, masalah kebersihan sering terabaikan terutama masalah kebersihan tangan.Hal ini menyebabkan banyaknya anak asuh yang terkena diare, cacing, dan tipes.

Salah satu hal yang melatarbelakangi hal tersebut adalah kurangnya pengetahuan akan pentingnya menjaga kebersihan tangan (Solehati dkk, 2015). Dalam memelihara kebersihan tangan tersebut, hal-hal yang perlu diperhatikan antara lain : mencuci tangan sebelum makan dan memotong kuku secara teratur.

Namun, cuci tangan belum menjadi budaya yang dilakukan oleh masyakarat di lingkungan ini. Dalam kehidupan seharihari, masih banyak anak yang mencuci tangan hanya dengan air saja saat sebelum makan. Cuci tangan dengan sabun seringkali dilakukan justru setelahmakan (Wati dkk, 2017).

Demikian juga dengan kebersihan kuku. Berdasarkan hasil pengamatan dan wawancaera, kuku anak asuh Rimbani tergolong kotor dan jarang sekali dipotong. Berdasarkan penelitian Purba, anak usia sekolah dasar yang memunyai kebiasaan potong kuku secara teratur dapat mengurangi kejadian cacingan (Purba $\mathrm{J}$, 2005).

Kebiasaan membersihkan tangan tersebut perlu diajarkan sejak kecil karena anak-anak merupakan agen perubahan bagi lingkungannya. Melalui kebiasaan tersebut, anak-anak diharapkan dapat memberikan contoh pada keluarga dan lingkungannya. Oleh karena itu, studi ini dilakukan untuk melihat pengaruh edukasi kebersihan tangan terhadap pengetahuan dan keterampilan membersihkan tangan anak di komunitas Anak Asuh Rimbani.

\section{METODE PENELITIAN}

Studi ini merupakan penelitian dengan desain pre-post test experimental untuk mengetahui pengetahuan anak sebelum dan sesudah dilakukan edukasi. Populasi dalam penelitian ini adalah anak kelas 2-4 sekolah dasar yang terdaftar sebagai penerima bantuan belajar di komunitas Anak Asuh Remaja Islam Baitul Mughni. Dengan teknik sampling jenuh dan peserta yang datang sebagai kriteria inklusiya, maka diperoleh 41 orang anak sebagai sampel penelitian.

Instrumen yang dilakukan dalam penelitian meliputi; media power point, lagu 7 langkah cuci tangan, dan kuesioner. Untuk melihat perbedaan ratarata pengetahuan anak sebelum dan sesusdh intervensi, dilakukan uji paired ttest. 
Izza Suraya, Yoli Farradika, dan Rina Khairunnisa

HASIL DAN PEMBAHASAN

Berdasarkan hasil studi yang dilakukan, jumlah responden penelitian adalah 41 orang, $26,83 \%$ kelas 2, 29,27

$\%$ kelas 3 , dan 43,90 \% adalah siswa kelas
4.

Tabel 1. Tingkat Pendidikan Peserta

\begin{tabular}{ccc}
\hline Kelas & Frekuensi & $\%$ \\
\hline 2 & 11 & 26,83 \\
3 & 12 & 29,27 \\
4 & 18 & 43,90 \\
& 41 & 100 \\
\hline
\end{tabular}

Hasil studi juga menunjukkan bahwa terjadi peningkatan pengetahuan peserta sebelum diberikan dengan setelah diberikan penyuluhan dengan nilai $p<0,001$. Rerata skor pre-test peserta adalah 2,93 $(S D=0,91)$ dan rerata skor post-test adalah $3,85(S D=1,04)$. Hal ini sejalan dengan penelitian yang dilakukan oleh Salaudeen (2011), Hamida(2012), dan Zulaekah (2012) yang mengatakan bahwa edukasi mamapu meningkatkan pengetahauan peserta.

Tabel 2. Perbedaan rata-rata tingkat pengetahuan anak asug sebelum dan sesudah edukasi kebersihan tangan

\begin{tabular}{llll}
\hline Pengetahuan & Mean & SD & Pvalue \\
\hline Sebelum Edukasi & 2,93 & 0,91 & \\
Sesudah Edukasi & 3,85 & 1,04 & $<0,0001$
\end{tabular}

Peserta merupakan ssiswa sekolah dengan keingintahuan yang tinggi. Dengan metode belajar dan bermain, peserta lebih banyak menyerap informasi yang disampaikan. Menurut Hamida (2012), media yang digunakandalam proses pembelajaran akan mempengaruhi proses penerimaan informasi siswa. Peningkatan pentahuan yang terjadi diharapkan dapat mebuat anak asuh paham akan pentingnya menjaga kebersihan tangan sehingga termotivasi untuk merubah perilaku cuci tangannya dalam kehidupan sehari-hari. Dengan demikian, anak dapat terhindar dari penyakit seperti diare, kecacingan, dan tipes.

\section{KESIMPULAN}

Penyuluhan dapat dinilai berhasil meningkatkan pemahaman dan keterampilan akan pentingnya kebersihan tangan anak Usia Sekolah Dasar di Komunitas Ank Asuh Rimbani, Jakarta Selatan. Hal ini terlihat dari meningkatnya 
pengetahuan mereka saat post test

dibandingkan dengan pre test.

\section{DAFTAR PUSTAKA}

A.K, Cicilia Presska, Trixie Salawati, dan Rahayu Astuti. 2012. Pengaruh Penyuluhan Kesehatan Tentang Kecacingan Terhadap Pengetahuan dan Sikap Mahasiswa Madrasah Ibtidaiyah An Nur Kelurahan Pedurungan Kidul Kota Semarang. Jurnal Promosi Kesehatan Indonesia, 7 (2), 184

JS, Slamet. 1996. Kesehatan Masyarakat dan Kesehatan Lingkungan, edisi ke-3. Yogyakarta : Gajah Mada University Press.

Purba J.2005. Pemeriksaan Telur Cacing Pada Kotoran Kuku Dan Higiene Siswa Sekolah Dasar Negeri Tanjung Rejo Kecamatan Percut Sei Tuan. Skripsi. USU.

Soekidjo Notoatmojo. 2007. Promosi Kesehatan dan IImu Perilaku. Jakarta : Rineka Cipta

Solehati, Tetti, Sri Susilawti, dan Cecep Eli Kosasih. 2015. Pengaruh Edukasi Terhadap Pengetahuan dan Skill Guru serta Personal Hygiene Siswa SD. Jurnal Kesehatan Masyarakat. 11(1)

Wati, Nasriah, Nani Yuniar, dan Paridah. 2017. Pengaruh Intervensi Penayangan Video Terhadap Pengetahuan, Sikap, dan Tindakan Tentang Cuci Tangan Pakai Sabun Pada Siswa SDN 10 Kabawo Tahun 2016. Jurnal Ilmiah Mahasiswa Kesehatan Masyarakat. , 2 (5). 